Research Article

\title{
EFL Teachers' Practices and Implementations of Speaking Activities in Ethiopian English Textbooks
}

\author{
Dereje Asfaw Bulbula (D), Tesfa Alemu Bulti, and Eyasu Yaya Sada $(D)$ \\ Department of English Language and Literature, College of Social Science and Humanties, Bonga University, P.O. Box 334, \\ Bonga, Ethiopia \\ Correspondence should be addressed to Dereje Asfaw Bulbula; dereasbuu@gmail.com
}

Received 18 July 2021; Revised 3 September 2021; Accepted 21 September 2021; Published 29 September 2021

Academic Editor: Yi-Shun Wang

Copyright (C) 2021 Dereje Asfaw Bulbula et al. This is an open access article distributed under the Creative Commons Attribution License, which permits unrestricted use, distribution, and reproduction in any medium, provided the original work is properly cited.

\begin{abstract}
Speaking activities are educational procedures used to motivate learners through experience and exposure. Therefore, this research investigated EFL teachers' practices and implementations of speaking skill activities in the Ethiopian grade 10 English textbooks. To achieve this objective, 72 grade 10 students, using simple random sampling techniques, were selected to fill in a questionnaire, and $4 \mathrm{EFL}$ teachers were taken using comprehensive sampling techniques for classroom observations and interviews. A descriptive case study research design with mixed methods of data collection and analysis was applied. In order to gather relevant data, one-month observations were carried out by the use of a checklist. Next, a questionnaire with a five-point Likert scale was administered to students. Finally, an interview was also conducted with EFL teachers. The data revealed that EFL teachers rarely present speaking skill activities, and even when they present, they did not motivate students and did not provide clear instructions. Moreover, they mostly used students' mother tongue (L1) by ignoring the target language, and they were limited only to some common activities and failed to use all or various techniques of presenting speaking skill activities. Therefore, EFL teachers are strongly recommended to follow the four stages of presenting the speaking skill activities.
\end{abstract}

\section{Introduction}

Language is a means of thinking and transferring culture from one generation to another as well as from one nation to another. It is also a means of communication among people. Hence, many countries emphasize teaching languages other than the native language to their citizens. Nowadays, English is the language for international communication, science, commerce, advertising, diplomacy, and transmitting advanced technology [1]. It became a medium of instruction in addition to the aforementioned use in Ethiopia; as a result, all methods and procedures used to teach the English language should be carefully analyzed and investigated each time in order to satisfy the national and international needs of the intended language in the educational context.

Similarly, the aim of language teaching and learning is commonly defined in relation to the four language skills: listening, reading, speaking, and writing. Depending on the language user's activity, Widdowson [1] grouped them into receptive and productive ones. Speaking is called one of the productive skills because it involves language production and gives a chance to teachers and students to communicate orally in the classroom. Nevertheless, Ur [2] indicated that (...) of all four skills (listening, speaking, reading, and writing), speaking seems intuitively the most important: people who know a language are referred to as "speakers" of that language as if speaking included all other kinds of knowledge, and many if not most foreign language learners are primarily interested in learning to speak [2].

Additionally, the major goal of English language teaching is to give learners the ability to use English effectively and enable students to become communicatively competent. This goal is achieved through teachers' practice and implementation of various strategies, and the way teachers use these strategies has a significant role in classroom practice. Investigating how teachers of the English language teach speaking skills and how 
they best help their country in creating active, knowledgeable, and competent students will have great global and local values. If teachers are deficient in methods of implementing speaking activities, learners lack opportunities to practice different speaking activities that are presented in the student textbook because learners can follow directions, perform different activities in the classroom, and overcome challenges if and only if they were properly instructed and supported by their teachers [3]. The textbook is one of the dominant means of teaching the English language in Ethiopia because English in Ethiopia is taught as a foreign language. Activities in the textbook should be carefully implemented by EFL teachers, and how these activities are implemented should be investigated over time.

The teaching and learning of the English language in Ethiopia are classroom dependent, and learners do not have exposure to practice all language skills, and of all skills, students do not have exposure to one of the macro language skills which is the speaking skill.

This indicated that there is a gap of knowledge and practice in using various techniques from different stakeholders, specifically from EFL teachers, on how to apply speaking skill activities and also on which techniques should be used while implementing speaking activities. Thus, the current study is based on the following research and knowledge gaps.

1.1. Statement of the Problem. A large percentage of the world's language learners study English to develop proficiency in speaking. The ability to speak a second or foreign language well is a very complex task if we try to understand the nature of what appears to be involved [4]. Similarly, in Ethiopia, most of the learners at secondary and preparatory school levels have problems with speaking English. Concerning this, the research findings by the MoE [5] stated that it is a widely held belief that the status of English is low in Ethiopian schools at all levels. Accordingly, the problem is common for all language skills, and speaking is one of the areas, which needs attention. As reported by Tamiru [6], most teachers in Ethiopian high schools are not proficient enough in English, which, as a result, is the cause for the great majority of the students' lack of basic language skills.

Moreover, different research studies in different parts of the world were conducted in this area, and to mention some of them, Gudu [7] conducted a study to determine the classroom activities used by teachers to promote learners' active participation in speaking lessons in eight secondary schools in Eldoret Municipality, Kenya. The study found that there was a variation in the use of classroom activities. For example, the discussion was the most used classroom activity, while the oral drill was the least used.

$\mathrm{Hu}$ and Huang [8] conducted related research on 'Teachers' and Students' Perceptions of Classroom Activities Commonly Used in English Speaking Classes.' The study found that teachers do not take students' perceptions and practices into consideration while designing classroom activities. Abu-Ghararah [9] also conducted research on 'Problems with Speaking Activities in the Saudi EFL Classroom.' In his findings, teachers stopped and corrected students every time they made a mistake while implementing speaking activities in EFL classes. Mistakes were not tolerated and were considered a serious problem and a source of shame.

Besides, some related research studies have been carried out in different local contexts. For example, Abdisa [10] conducted research on the classroom practice of teaching speaking skills at Ayer Tena Secondary School. His findings depicted that inappropriate speaking techniques and procedures were used. Teachers were observed using the traditional way of teaching speaking, which is dominated by reading model dialogues allowed. There has been little or no time given for modern speaking skills and teaching techniques such as group and pair discussions, oral reports, drama, panel discussions and interviews. Sisay [11] also tried to determine the challenges English teachers face while teaching speaking skills and see what strategies teachers employ to promote speaking skills in the context of large classrooms. According to his findings, the challenges that hinder teachers in implementing speaking activities were that classrooms were not convenient for pair and group work. The chairs and desks were not moveable.

Another research study conducted by Amanuel [3] mainly focused on problems that affect students' speaking skills. Classes were mostly teacher-dominated. Accordingly, the majority of students were supposed to listen to their teachers' talk. He also indicated the existence of problems related to teachers, such as negative beliefs about language teaching, lack of training, and ineffective teaching methodology.

Therefore, this study is different from the above global and local studies in the following ways: (1) all of them focused on the general speaking ability of teachers and students, but this study mainly focused on examining EFL teachers' practice and implementation of speaking activities in the Ethiopian grade 10 English language textbook. Therefore, the main concern of this study is on teachers' implementation, the challenges that teachers face, and the techniques teachers use rather than the practice of the students. (2) They mainly focused on factors affecting students' speaking skills in large classrooms. The present study focused on the challenges that teachers face while presenting speaking activities. (3) They did not address the effective activities to be used while implementing speaking activities. However, this study puts into consideration the activities used in implementing the speaking activities. Therefore, this study tries to address the following leading questions.

1.2. Basic Research Questions. This study attempted to answer four leading research questions: they are as follows: (1) how do high school EFL teachers present the speaking skill activities in the student English language textbook? (2) In what manner do high school EFL teachers present speaking skill activities in the textbook for students? (3) What are the activity types that high school EFL teachers use in presenting the speaking skill activities? (4) What are the challenges that high school EFL teachers face while presenting speaking activities? 


\section{Literature Review}

The present section is devoted to briefly present an overview of what the speaking skill is and the type of speaking activities. An attempt is also made to critically present the theoretical and practical aspects of the literature in the area of the challenges teachers are facing while implementing speaking activities as follows.

2.1. The Need of Speaking Activities. Speech is the most distinguishing feature of humans from other living creatures. It is a natural state of language, in which all human beings are born to speak their mother tongue; moreover, speech is activated when people use their voice to express opinions, suggestions, information, and even criticism. When talking about a certain issue, of course, we have to understand many things $[12,13]$.

Rodgers and Richards and Nunan $[14,15]$ argued that teachers have to make decisions about the appropriate kinds of tasks (the sequence in which tasks should be introduced); pacing (how much time learners should spend on tasks); products (whether the product or result of a task is expected to be the same for all students); and learning strategies (what learning strategies will be recommended for particular tasks). Furthermore, (ibid) we have also asserted that speaking activities need to maximize the production of the language to provide the best conditions for autonomous language use. Meanwhile, the function of speaking including talk as a transaction aims to exchange information or goods, and talk as an interaction aims to maintain a social relationship $[13,16]$.

(i) The above point was discussed to show that the need for speaking activities is immense, and they help develop the exchange of ideas and maintain relationships. In line with this, let us look at successful speaking. Successful speaking activities, according to Ur [17], have the following characteristics:

(ii) Motivation is high: learners are eager to talk because they are passionate about the subject and have something new to contribute. This indicates that kids have genuine willingness to participate in a communication activity.

(iii) Learners talk a lot: the learners' lecture will take up a large portion of the time provided for the exercise. The teacher's intervention is not welcome. Giving pupils a lot of time to chat can help to establish the greatest environment for oral activities.

(iv) Participation is even: a small group of noisy students should not dominate classroom activity. All pupils should be encouraged to speak, and contributions should be spread equitably.

2.2. Challenges in Implementing English Speaking Activities. According to Ur and Littlewood [2, 18], four main problems can challenge teachers in getting students to speak in the foreign language in the classroom. They are inhibition (lack of real exposure and learner's fear of making a mistake), nothing to say (students even do not know what to say in English), low or uneven participation (lack of participation or involvement in the activity), and mother tongue use (students in EFL context always do not use English rather they use mother tongue or L1. They do not participate in the class in English which is a target language).

As it has been discussed above, we can infer that most of the challenges that hinder students not to practice speaking in the classroom resulted from nervousness, shyness, low participation, and mother tongue influence.

2.3. Activities in Implementing English Speaking Activities. Shrouf, Parrott, Harmer, and Bryson [19-22] listed out that there are different kinds of techniques and activity types that the teacher should use to teach speaking. They are discussions (activities in which the learners discuss and come up with the result), role play (an activity in which learners take part), simulations (letting students bring items to the class to create a realistic environment), information gap (students should share ideas from each to fill the gap), brainstorming (students can produce any ideas in a limited time), interviews (students can conduct interviews on selected topics with various people), storytelling (summarizing a tale or story they heard from somebody or created by themselves), and picture narrating (give students just one picture and having them describe what it is in the picture).

In line with the aforementioned speaking activities, the researchers developed the research question which addresses what activities are being used to teach and develop speaking skills. This literature review is a base for the very activities of speaking in the class.

2.4. Teachers' Roles in Implementing Speaking Activities. Rodgers and Richards [14] clearly stated that EFL teachers should play a significant role in teaching and implementing speaking activities. Furthermore, Rodgers and Richards, Littlewood, and Harmer [14, 23, 24] disclosed the roles a language teacher needs to play in communicative classrooms as follows:

(i) Need analyst: responsible to determine and address the learners' language needs

(ii) Counselor: takes the responsibility for reconciling misunderstandings among interlocutors to maximize communication through paraphrasing, confirmation, and feedback

(iii) Manager: manages the ongoing group processes in the classroom setting for communication and communicative activities

(iv) Resource: being a knowledge provider offers the necessary help when the learners are missing and they deserve assistance

As the above discussion shows, the roles of teachers in the class need to be immense in addressing the need of students, advising the students, managing the communicative activities in the class, and helping the students with different resources. 


\section{Research Method}

In this section, the design is presented, the participants are described, and the materials and procedures for data collection and analyses are clearly specified and discussed as follows.

3.1. Research Design. Since the primary objective of this study was to examine EFL teachers' practice and implementation of speaking skill activities in the Ethiopian grade 10 English language textbook, a descriptive research design was believed to be suitable and used in this study. Descriptive research design according to Gerring [25] focuses on investigating certain topic that specifically focuses on providing an answer for the "what" of the phenomenon or topic under investigation. Moreover, a researcher can conduct descriptive research using specific methods such as the observational method, case study method, and survey method. Between these three, all primary data collection methods are covered, which provide a lot of information on the topic under investigation. Therefore, a descriptive research design with the case study and observational method was used in this study as it is relevant to answer a research question formulated by researchers and helps to achieve the objectives of the current study. Additionally, since the primary goal set by the researchers was to describe the data as they occur and to identity EFL teachers practice and the strategies they use while implementing speaking skill activities, this research used both quantitative and qualitative types of data and method of data collection with the help of descriptive research design. This was done due to the reason that the method and design used in this study is the best and suitable to attain and achieve the objectives of the study $[25,26]$.

3.2. Participants and Sampling Techniques. To conduct this study, a total of 72 students (25 female and 47 male), who were registered in the $2012 \mathrm{EC}$, and 4 EFL teachers who were assigned to teach grade ten were the participants of this study. The age of students who participated in this study was found between 16 and 20, and teachers' age ranged between 29 and 42. As students are sole individuals that have direct contact with teachers, students in this study were selected as participants for two reasons: first, the researchers intended to identify how their EFL teachers implement speaking activities in their classes and secondly, to know the kind of activities their teachers use while implementing speaking skill activities. Similarly, EFL teachers were also taken as participants of this study in order to get relevant data about how they implement speaking skill activities and challenges they face while implementing. Moreover, they were also selected to triangulate data collected from students.

The first and foremost researcher of this study went to Gimbo Secondary and Preparatory School which is found in SNNPR, Kafa Zone, Gimbo Town, and contacted the school principal for their willingness to participate in this research and also to get relevant information about target populations. After getting permission and relevant information from the school principal, the researchers proceeded to identify the sample. There were only four English language teachers teaching the English language in the intended school, and this study took all of them by using a comprehensive sampling technique. A comprehensive sampling technique was used to select the participants that were available and easy to manage [27]. Therefore, the number of teachers is small and easy to manage, and this is why a comprehensive sampling technique was used to take all teachers. Then, the researchers contacted all of the teachers and obtained their willingness to participate in the study as a source of data. On the contrary, as data gained from the intended school principal indicated, there were a total of 241 students in grade ten, and they were divided into four sections in 2012 EC. From the total, 30\% of the students were selected as the participants of this study by using simple random sampling through a lottery system. The selected students were also communicated first by the researchers, and they confirmed their willingness to participate in this study and to give relevant data. On this, Lund [28] pointed out that "For small populations (under 1,000), a researcher needs a large sampling ratio (about 30 percent)." Moreover, Cohen et al. [29] stated that, in simple random sampling, each member of the population under study has an equal chance of being selected. Thus, based on the aforementioned authors' recommendation, 72 (30\%) students were selected and exposed to fill in the questionnaire.

3.3. Instruments. Questionnaires, classroom observations, and interviews were used to gather relevant data and achieve the intended objectives.

Firstly, a questionnaire that elicits an answer for the first research question of the current study which is about "how do high school EFL teachers present the speaking skill activities in the student's English language textbook?" was adapted from $[7,10]$ within the form of five-point Likert type and designed in the form of the close-ended item. This questionnaire was composed of eight items, and each of them was designed with a five-point Likert type that ranges from "strongly agree" to "strongly disagree" with values of 5 to 1 , respectively. Similarly, a questionnaire with five items with five-point Likert type was also adapted from $[7,10]$ to elicit answers for the second research question that asks about "in what manner do high school EFL teachers present speaking skill activities in the textbook for students?" and also to find an answer for the third research question which elicits about "what are the activity types that high school EFL teachers use in presenting the speaking skill activities?" A questionnaire for data collection was designed in the form of five Likert scale by the use of frequency levels, and arranged from 5-1 or from always to never, and it has a total of eight items, and adapted from $[7,10]$. Therefore, the adapted questionnaire was carefully and slightly modified to the context of the current study and objective and finally distributed to students in order to gather relevant data.

Additionally, the researchers also prepared an observation checklist based on the research objective and made structured observations. On this, Yeabsira [30] asserted that observation is very useful in exploring topics that may be uncomfortable for participants to discuss. Moreover, as Yeabsira [30] pointed out, observation gives fresh and first- 
hand information about the subject observed; as a result, observation in this study is used because of two reasons: (1) to substantiate data from the student questionnaire and to get some relevant data missed in case of the questionnaire on "what are the activity types that high school EFL teachers use in presenting the speaking skill activities?" and (2) to observe the actual classroom while teaching and learning are going on and to get data about "what are the challenges that high school EFL teachers face while presenting speaking activities?"

The classroom observations that were supported by the checklist were conducted by the researchers for one month. All four EFL teachers were observed; for three times, each teacher's teaching speaking skills were assessed on various days, and a total of twelve classroom observations that took 480 minutes were made for one month so as to elicit an answer for the aforementioned research questions. The researchers did not observe while EFL teachers teach language skills such as reading, writing, and listening; they rather observed only by the time EFL teachers teach speaking skills. The reason why the observations were supported by the checklist was to avoid the potential personal bias that might occur in the data collected on what was being observed; then, the researcher carried out the observations of grade 10 (sections A, B, C, and D) teachers teaching the English language. The relevance of observation and its suitability to the current research was confirmed by Yeabsira [30].

Moreover, interview was the other data-gathering instrument used in this study. A semistructured interview that has five interview questions that were prepared based on the existing literature focusing on the objective of the current study was prepared by the researchers and conducted with all EFL teachers in a detailed manner. The interview was used in this study for two reasons: (1) in order to come up with a reasonable explanation and enrich the study; (2) in order to substantiate data from students' questionnaires and classroom observations. From all research questions, the final one which elicits "what are the challenges that high school EFL teachers face while presenting speaking activities?" obtained detailed attention on the interview. According to Keefe and Jenkins [31], semistructured interviews can help the researchers to get detailed themes and topics which may not be directly explained. Therefore, the interview questions were developed beforehand by the researchers and conducted with all EFL teachers discretely for 15 minutes each, and a total of one-hour interview is conducted and noted by the researchers. An interview is conducted in a face-to-face situation with the EFL teachers in the school compound after the data were collected from the questionnaires and classroom observations.

3.4. Procedures of Data Collection. In order to successfully achieve the objective of this study, different steps and strategies of data collection procedures were followed by the researchers. In the first step, the researchers selected a specific research design and method that best helps the researcher to achieve the intended objective. Then, all datagathering instruments were carefully adapted, designed, pilot-tested, and also given to different experts for comments and modification before the distributions. All comments from experts and the pilot study were corrected on the final version of the data-gathering instruments.

In collecting the data for this study, all necessary ethical procedures were followed. First, researchers contacted the school principal for the selection and identification of participants of the study and to check their availability. After getting permission from the school principal, the researchers selected the participants by following all scientific procedures and identified the sample from the total population. After the identification of the sample, all of the sample students were gathered to one hall, clearly explained about the purpose of the research, instructed to give all necessary data without any hesitation, and also informed that the data they give are used only for the current research purpose because of their confidentiality. The sample students were allowed to ask any question while filling the questionnaire and were ordered not to write their names in any part of the questionnaire. The selection of student samples was carried out using lists of students collected from homeroom teachers giving an equal proportion for each participant. The final draft of the questionnaire was administered to 72 (47 male and 25 female) grade 10 students.

In the beginning, classroom observation was conducted. The reason why observations were made first was to minimize the artificial reaction of the respondents when observed after the questionnaire dissemination. Observations were primarily conducted for the purpose of identifying types of speaking activities used by EFL teachers, knowing the way EFL teachers present speaking activities, and to identify challenges EFL teachers face while implementing speaking activities. The observation that was supported by checklists took over one-month period beginning before administering the questionnaire because it was conducted based on arrangements of place and time in accordance with the convenience of the informants.

Next, after the researchers gathered the sample students in a separate room, the researchers distributed the questionnaire, read the cover page of the questionnaire to the students, and explained the objective of the study before they answered the questionnaire. Participants' confidentiality was guaranteed by using responses only for the research purpose. The students completed the questionnaire in approximately 45 minutes. The purpose was to identify how EFL teachers present speaking activities, how frequently EFL teachers use different types of activities, and the manner in which speaking activities are presented in EFL classes.

In the end, a total of 1-hour interviews with $4 \mathrm{EFL}$ teachers, 15 minutes each, were conducted. Before the beginning of an interview, first, the purpose of the interview was clearly introduced to all of the teachers briefly, and then a semistructured interview was conducted with all of them. The purpose of the interview was dominantly to know the challenges EFL teachers faced while implementing speaking activities and secondly to cross-check and substantiate data from classroom observations and student questionnaires. Five interview questions were prepared based on the objective of the study and forwarded to the informants. In 
order to not miss the data, the researchers took notes and audio-recorded an interview session carefully.

3.5. Method of Data Analysis. The collected data by the use of three data-gathering instruments such as a questionnaire for students, classroom observations both for teachers and students, and an interview with all EFL teachers were presented and analyzed using various scientific procedures. Firstly, the data obtained from the students' questionnaire were tailed and tabulated into SPSS version 21 and then analyzed by the use of descriptive statistics with the help of a quantitative method. The data were presented in a table form by using frequency (percentage), grand mean, and mean value for each item and then interpreted using mean value and percentage. Then, all analyses from the questionnaire were made based on the leading research questions discretely and presented one after the other in the result section. Moreover, the data from the students' questionnaire were triangulated with the data from classroom observation and an interview when necessary. This was done to show the consistency and inconsistency of data from various instruments.

Similarly, data collected from classroom observations with the help of checklists were analyzed quantitatively and presented in amalgamation with data from students' questionnaires and also discretely presented and interpreted.

However, the data obtained through the interview with EFL teachers were analyzed qualitatively. This was done by grouping the data into themes, and then each response was grouped and described thematically. Finally, to triangulate the data, both data obtained from the students' questionnaire and the teachers' interview were compared with the data obtained from the classroom observation. In general, the discussion of all major findings of this study was compared to the existing literature and with the previous research conducted in the area, and its discussion is presented near the end of the data analysis.

\section{Results}

This section tries to present the results of the research, and at the same time, it gives comprehensive discussions. As [2, 5], results of any study can be presented in figures, graphs, tables, and others that make the reader understand easily. Thus, as per the recommendation by the above scholar, the finding of this study is presented in table forms and interpreted in various forms following each table. According to [5], the discussion can be made in several sections, but in this study, it was presented near the end of this section. This part presents the data results of the study. The data collected using questionnaires, classroom observations, and interviews are clearly presented and analyzed. The basic research questions were addressed, and the objectives were also met in this section.

Research question 1: how do high school EFL teachers present the speaking activities in the student English language textbook?
As it is shown in Table 1, the mean score for item number 1.1 is 2.7 . This reveals that the majority of the respondents (38 (52.79\%)) answered that they strongly disagree that their teachers did not make the instruction clear while presenting speaking activities.

In response to item 1.2, the respondents indicated a mean value of 2.4 , which showed that the majority of students $(54.1 \%)$ indicated that teachers did not encourage students while presenting speaking activities, whereas in item $1.3,45.8 \%$ of the respondents with a mean value of 2.1 indicated that EFL teachers did not put pressure on students while presenting speaking activities. On item 1.4, 61.1\% of the respondents with 2.3 of the mean value responded that teachers did not give equal chance to all students while presenting speaking activities in their classrooms.

$54.22 \%$ with a mean value of 4.3 agreed with item 1.5 and indicated that teachers did not present speaking activities. Instead, they implemented grammar and vocabulary sections. In item 1.6, the respondents (50\%) with a mean score of 2.4 indicated that teachers did not motivate their students while presenting speaking activities. As it is shown in item number 1.7, teachers did not help their students when they faced unclear activities while implementing speaking activities as $43 \%$ with a mean value of 2.5 disagreed. In response to item 1.8 , the majority of the respondents $(59.7 \%)$ with a mean score of 2.1 indicated that EFL teachers took much time while implementing the speaking activities, so they did not provide sufficient time for discussion and presentation while presenting speaking activities.

Research question 2: in what manner do high school EFL teachers present speaking skill activities in the English language textbook for students?

As it is clearly presented in Table 2 , in response to items $2.1,2.3,2.4$, and 2.5 , students disagreed with the items with mean values of $2.8,2.3,2.5$, and 2.5 , respectively. The response indicated that the way EFL teachers present speaking activities was not in an enjoyable manner. Teachers did not present different speaking activities in their classrooms, the speaking activities that were presented by the teachers did not motivate the students to speak freely, and the speaking activities that were presented by the teachers did not incorporate the students' participation, whereas in item 2.2, the majority of students $(54.2 \%)$ with a mean value of 3.0 responded undecided, and this indicated that the speaking activity helped them to speak and work well.

The interview data from EFL teachers also revealed that the implementation of speaking activities was the most challenging activity for them, but they did not regularly present the speaking activities that are designed in the student textbook. They responded that most students in the class were not interested in speaking in front of their classmates. Additionally, learners were not willing to interact. EFL teachers did not use various activities as much as expected. The reason they stated was that students were not interested in practicing speaking in the classroom. Their lack of interest affects the time given for the lesson, and the learners do not spend much time presenting speaking activities. In relation to this, when students are told to discuss in groups or assigned to practice a type of activity in the 
TABle 1: Students' response to how their EFL teachers implement English speaking activities.

\begin{tabular}{|c|c|c|c|c|c|c|c|c|c|}
\hline No. & Item: EFL teachers & $\begin{array}{l}\text { Frequency } \\
\text { and } \%\end{array}$ & $\begin{array}{l}\text { Strongly } \\
\text { agree (5) }\end{array}$ & $\begin{array}{l}\text { Agree } \\
(4)\end{array}$ & $\begin{array}{l}\text { Undecided } \\
\text { (3) }\end{array}$ & $\begin{array}{l}\text { Disagree } \\
(2)\end{array}$ & $\begin{array}{l}\text { S/disagree } \\
(1)\end{array}$ & Total & Mean \\
\hline \multirow{2}{*}{1.1} & Make the instructions of the speaking & Fre & & 4 & 30 & 38 & & 72 & 2.7 \\
\hline & activities clear & $\%$ & & 5.55 & 41.66 & 52.79 & & 100 & \\
\hline \multirow{2}{*}{1.2} & Encourage students to practice the & Fre & & 3 & 26 & 39 & 4 & 72 & 2.4 \\
\hline & speaking activities & $\%$ & & 4.1 & 36.25 & 54.1 & 5.55 & 100 & \\
\hline \multirow{2}{*}{1.3} & Put pressure upon students to perform & Fre & & 6 & 12 & 33 & 21 & 72 & 2.1 \\
\hline & well in the speaking classroom & $\%$ & & 8.33 & 16.67 & 45.8 & 29.2 & 100 & \\
\hline \multirow{2}{*}{1.4} & Give equal chance to all students while & Fre & & 5 & 17 & 44 & 6 & 72 & 2.3 \\
\hline & presenting speaking activities & $\%$ & & 6.9 & 23.67 & 61.1 & 8.33 & 100 & \\
\hline \multirow{2}{*}{1.5} & Prefer to teach grammar and vocabulary & Fre & 27 & 39 & 4 & 2 & & 72 & 4.3 \\
\hline & to present speaking activities & $\%$ & 37.5 & 54.22 & 5.5 & 2.78 & & 100 & \\
\hline \multirow{2}{*}{1.6} & Motivate their learners while presenting & Fre & & 7 & 21 & 36 & 8 & 72 & 2.4 \\
\hline & the speaking activities & $\%$ & & 9.7 & 29.2 & 50 & 11.1 & 100 & \\
\hline \multirow[b]{2}{*}{1.7} & Help the students when they face & Fre & & 11 & 23 & 31 & 7 & 72 & 2.5 \\
\hline & $\begin{array}{l}\text { unclear activities in presenting speaking } \\
\text { activities }\end{array}$ & $\%$ & & 15.4 & 31.9 & 43 & 9.7 & 100 & \\
\hline \multirow{3}{*}{1.8} & Provide sufficient time for discussion & Fre & & 6 & 11 & 43 & 12 & 72 & 2.1 \\
\hline & $\begin{array}{c}\text { and presentation while presenting } \\
\text { speaking activities }\end{array}$ & $\%$ & & 8.3 & 15.3 & 59.7 & 16.7 & 100 & \\
\hline & Total mean & & & & & & & & 2.6 \\
\hline
\end{tabular}

TABLE 2: Students' responses on the way EFL teachers present speaking activities for students in the classroom.

\begin{tabular}{|c|c|c|c|c|c|c|c|c|c|}
\hline No. & Item & $\begin{array}{l}\text { Frequency } \\
\quad \text { and } \%\end{array}$ & $\begin{array}{l}\text { Strongly } \\
\text { agree (5) }\end{array}$ & $\begin{array}{l}\text { Agree } \\
(4)\end{array}$ & $\begin{array}{l}\text { Undecided } \\
\text { (3) }\end{array}$ & $\begin{array}{l}\text { Disagree } \\
\text { (2) }\end{array}$ & $\begin{array}{c}\text { Strongly } \\
\text { disagree (1) }\end{array}$ & Total & Mean \\
\hline 2.1 & $\begin{array}{l}\text { The teachers present the activities in an } \\
\text { enjoyable way }\end{array}$ & $\begin{array}{c}\text { Fre } \\
\%\end{array}$ & $\begin{array}{c}4 \\
5.5\end{array}$ & $\begin{array}{c}7 \\
9.7\end{array}$ & $\begin{array}{c}21 \\
29.2\end{array}$ & $\begin{array}{c}37 \\
51.4\end{array}$ & $\begin{array}{c}3 \\
4.2\end{array}$ & $\begin{array}{c}72 \\
100\end{array}$ & 2.8 \\
\hline 2.2 & $\begin{array}{l}\text { The speaking activities help students to } \\
\text { speak and work well in the classroom }\end{array}$ & $\begin{array}{c}\text { Fre } \\
\%\end{array}$ & $\begin{array}{c}5 \\
6.9\end{array}$ & $\begin{array}{c}13 \\
18.1\end{array}$ & $\begin{array}{c}39 \\
54.2\end{array}$ & $\begin{array}{c}10 \\
13.9\end{array}$ & $\begin{array}{c}5 \\
6.9\end{array}$ & $\begin{array}{c}72 \\
100\end{array}$ & 3.0 \\
\hline 2.3 & $\begin{array}{l}\text { The speaking activities that are presented } \\
\text { by the teachers are varied }\end{array}$ & $\begin{array}{c}\text { Fre } \\
\%\end{array}$ & & $\begin{array}{c}5 \\
6.9\end{array}$ & $\begin{array}{c}21 \\
29.2\end{array}$ & $\begin{array}{c}43 \\
59.7\end{array}$ & $\begin{array}{c}3 \\
4.2\end{array}$ & $\begin{array}{c}72 \\
100\end{array}$ & 2.3 \\
\hline 2.4 & $\begin{array}{l}\text { The speaking activities presented by } \\
\text { teachers motivate students to speak freely }\end{array}$ & $\begin{array}{c}\text { Fre } \\
\%\end{array}$ & & $\begin{array}{c}7 \\
9.7 \\
\end{array}$ & $\begin{array}{c}25 \\
34.7\end{array}$ & $\begin{array}{c}38 \\
52.8\end{array}$ & $\begin{array}{c}2 \\
2.8 \\
\end{array}$ & $\begin{array}{c}72 \\
100\end{array}$ & 2.5 \\
\hline 2.5 & $\begin{array}{l}\text { The speaking activities that are presented } \\
\text { by the teachers require the students to } \\
\text { express and interact with their ideas in } \\
\text { the classroom }\end{array}$ & Fre & & 12.5 & 30.6 & 56.9 & & 100 & 2.5 \\
\hline & Total mean & & & & & & & & 2.6 \\
\hline
\end{tabular}

class, they refuse to do it, or they use their mother tongue mostly in the classroom. EFL teachers in their interview also mentioned the lack of supplementary materials such as samples of films or videos that helped the teachers to present the speaking activities in the classroom.

To triangulate data from teachers' interviews and students' questionnaires, classroom observations were also made, and the observation data confirmed the aforementioned data.

Research question 3: what are the activity types that high school EFL teachers use in presenting the speaking skill activities?

As it is clearly seen from Table 3, students rarely use language games (62.5), role play (58.33), picture describing (54.16), interview (51.38), storytelling (45.83), discussion (45.8), brainstorming (44.44), story completion (43.05), and information gap (37.5), respectively, whereas students also indicated that simulation, picture narrating, and finding the difference were never used by EFL teachers as techniques to implement speaking activities. Moreover, as with the classroom observations, EFL teachers were also observed while practicing some of the activities in Table 3 rarely.

Research question 4: what are the challenges that EFL teachers face while implementing speaking activities in the English textbook?

The challenges teachers faced during the implementation of speaking activities were gathered through teachers' interviews and classroom observations by four EFL teachers. EFL teachers pointed out that they faced different challenges in presenting the speaking activities. First, the teachers do not present varied speaking activities that affect the learners' habit of communicating in the classroom. Second, due to the 
TABLE 3: Students' responses about the activity types that are used by EFL teachers while teaching speaking skills.

\begin{tabular}{|c|c|c|c|c|c|c|c|c|c|}
\hline No. & Items & Frequency and \% & Always (5) & Usually (4) & Sometimes (3) & Rarely (2) & Never (1) & Total & Mean \\
\hline 1 & Discussion & $\begin{array}{c}\text { Fre } \\
\%\end{array}$ & $\begin{array}{c}4 \\
5.55\end{array}$ & $\begin{array}{c}8 \\
11.11\end{array}$ & $\begin{array}{c}17 \\
23.61\end{array}$ & $\begin{array}{c}33 \\
45.8\end{array}$ & $\begin{array}{c}10 \\
13.89\end{array}$ & $\begin{array}{c}72 \\
100\end{array}$ & 2.4 \\
\hline 2 & Role play & $\begin{array}{c}\text { Fre } \\
\%\end{array}$ & & $\begin{array}{c}4 \\
5.55\end{array}$ & $\begin{array}{c}13 \\
18.05\end{array}$ & $\begin{array}{c}42 \\
58.33\end{array}$ & $\begin{array}{c}13 \\
18.05\end{array}$ & $\begin{array}{c}72 \\
100\end{array}$ & 2.1 \\
\hline 3 & Simulations & $\begin{array}{c}\text { Fre } \\
\%\end{array}$ & & & & & $\begin{array}{c}72 \\
100\end{array}$ & $\begin{array}{c}0 \\
0 \%\end{array}$ & 0 \\
\hline 4 & Information gap & $\begin{array}{c}\text { Fre } \\
\% \\
\end{array}$ & & $\begin{array}{c}11 \\
15.27 \\
\end{array}$ & $\begin{array}{c}21 \\
29.16 \\
\end{array}$ & $\begin{array}{c}27 \\
37.5 \\
\end{array}$ & $\begin{array}{c}13 \\
18.05\end{array}$ & $\begin{array}{c}72 \\
100\end{array}$ & 2.4 \\
\hline 5 & Brainstorming & $\begin{array}{c}\text { Fre } \\
\%\end{array}$ & $\begin{array}{c}3 \\
4.16 \\
\end{array}$ & $\begin{array}{c}8 \\
11.11 \\
\end{array}$ & $\begin{array}{c}13 \\
18.05 \\
\end{array}$ & $\begin{array}{c}32 \\
44.44 \\
\end{array}$ & $\begin{array}{c}16 \\
22.22 \\
\end{array}$ & $\begin{array}{c}72 \\
100 \\
\end{array}$ & 2.3 \\
\hline 6 & Storytelling & $\begin{array}{c}\text { Fre } \\
\%\end{array}$ & $\begin{array}{c}2 \\
2.78\end{array}$ & $\begin{array}{c}16 \\
22.22\end{array}$ & $\begin{array}{c}21 \\
29.16\end{array}$ & $\begin{array}{c}33 \\
45.83\end{array}$ & & $\begin{array}{c}72 \\
100\end{array}$ & 2.8 \\
\hline 7 & Interview & $\begin{array}{c}\text { Fre } \\
\%\end{array}$ & & $\begin{array}{c}3 \\
4.16 \\
\end{array}$ & $\begin{array}{c}11 \\
15.27 \\
\end{array}$ & $\begin{array}{c}37 \\
51.38\end{array}$ & $\begin{array}{c}21 \\
29.16\end{array}$ & $\begin{array}{c}72 \\
100 \\
\end{array}$ & 1.9 \\
\hline 8 & Story completion & $\begin{array}{c}\text { Fre } \\
\%\end{array}$ & $\begin{array}{c}6 \\
8.33 \\
\end{array}$ & $\begin{array}{c}12 \\
16.67 \\
\end{array}$ & $\begin{array}{c}15 \\
20.83 \\
\end{array}$ & $\begin{array}{c}31 \\
43.05 \\
\end{array}$ & $\begin{array}{c}8 \\
11.11 \\
\end{array}$ & $\begin{array}{c}72 \\
100 \\
\end{array}$ & 2.6 \\
\hline 9 & Picture narrating & $\begin{array}{c}\text { Fre } \\
\% \\
\end{array}$ & & & & & & $\begin{array}{c}0 \\
0 \% \\
\end{array}$ & 0 \\
\hline 10 & Picture describing & $\begin{array}{c}\text { Fre } \\
\% \\
\end{array}$ & $\begin{array}{c}5 \\
6.94 \\
\end{array}$ & $\begin{array}{c}11 \\
15.27 \\
\end{array}$ & $\begin{array}{c}13 \\
18.05 \\
\end{array}$ & $\begin{array}{c}39 \\
54.16 \\
\end{array}$ & $\begin{array}{c}4 \\
5.56 \\
\end{array}$ & $\begin{array}{c}72 \\
100 \\
\end{array}$ & 2.7 \\
\hline 11 & Finding the difference & $\begin{array}{c}\text { Fre } \\
\% \\
\end{array}$ & & & & & & $\begin{array}{c}0 \\
0 \% \\
\end{array}$ & 0 \\
\hline 12 & Language game & $\begin{array}{c}\text { Fre } \\
\%\end{array}$ & $\begin{array}{c}2 \\
2.78\end{array}$ & $\begin{array}{c}7 \\
9.72\end{array}$ & $\begin{array}{l}18 \\
25\end{array}$ & $\begin{array}{c}45 \\
62.5\end{array}$ & & $\begin{array}{c}72 \\
100\end{array}$ & 2.5 \\
\hline & Total mean & $\begin{array}{c}\text { Fre } \\
\%\end{array}$ & $\begin{array}{l}3.71 \\
5.15\end{array}$ & $\begin{array}{c}8.18 \\
11.32\end{array}$ & $\begin{array}{l}16.25 \\
22.45\end{array}$ & $\begin{array}{l}38.08 \\
50.89\end{array}$ & $\begin{array}{c}10.67 \\
14.6\end{array}$ & $\begin{array}{c}72 \\
100\end{array}$ & 2.3 \\
\hline
\end{tabular}

shortage of time, they do not give enough time to their students. If they give themselves enough time, they do not use the target language in their discussions. One of the teachers, in his interview, said: "Teaching speaking in the context of this school is too difficult as we English teachers are few in number and the number of the students in one class are high in number, so it is too difficult to give equal chance for all student to speak and as a teacher we rush to cover the content of the course only." This indicated that the number of students, the content of the textbook, and the number of students in one class were the major problems for teachers not presenting speaking activities in an effective way. These data consist of data from observations. Another problem forwarded by teachers is that they do not give supportive feedback whenever the students make a mistake. Finally, the student textbook mainly focuses on grammar. Another EFL teacher replied as "the content of the course forced me not to give emphasis on speaking rather I inclined to teach grammar aspect most of the time." Therefore, EFL teachers were forced to teach more grammar than speaking due to the content of the textbook having emphasis on it. This also indicated that speaking skills and their activities are neglected by teachers. Moreover, the number of students who are assigned to one section highly affects the implementation of the speaking activities. In relation to this, the teachers preferred to present the speaking activities by themselves because of the shortage of time and lack of interest of the students. Almost all of them stated that the time was not enough to arrange the students to deal with that part because when they were trying to deal with that part, they had to adjust the students in their group, and it takes time to do so. Moreover, one of the interviewees replied as "I can say that 98 percent of the student in section I am assigned to teach do not have an interest to speak in the class and even they afraid of not to make a mistake in front of their friend..... even students only few not more than two students that have an interest to participate in speaking skills, so this skills make my class worse and disgusting." Therefore, as to the response, the other problem teachers face is the domination of some students. Some students are not interested in saying anything or expressing their feelings because they fear speaking in front of their friends or because of the lack of experience. Therefore, teachers are forced to follow those who lead the class only. Even teachers do not prefer to teach speaking skills because of the silence of the students in the class. Finally, all of the respondents in their interview mentioned that the challenges they faced in their sections were their students' unwillingness to participate during the speaking lessons. They (students) were hardly seen participating in activities such as interviews, role play/drama, oral reports, panel discussions, or debating. The reason is that they are afraid of speaking in front of their classmates. The other problem is that when the teachers order the students to discuss in class, some students do their personal activities. Besides, most students do not bring their English textbooks to their classroom. This problem reveals that teachers do not use different techniques, for example, picture narrating or picture describing. As a result, the 
students do not practice the activity, either. Data from classroom observations also revealed and confirmed the aforementioned problems.

\section{Discussion}

In this part, the data that had been gathered and analyzed were discussed under three major themes in response to the three basic research questions. The major findings of the study were briefly discussed and substantiated by other literature studies, taking the following key themes of the study into account:

(1) EFL teachers' implementation of speaking activities

(2) The activities EFL teachers use in implementing speaking activities

(3) The manner in which EFL teachers present speaking activities in the EFL class

(4) Challenges teachers face during the implementation of speaking activities

The first research question was aimed at determining how EFL teachers implement speaking activities in their classrooms. The overall findings indicate that English language teachers in the intended high school did not usually present speaking activities in their classrooms. It showed that teachers strongly favor the implementation of speaking activities. However, only a few teachers present the speaking activities partially. The findings of this study are in line with the study conducted at Ayer Tena Secondary School that was conducted by Abdisa [10]. The results of his findings indicated that most teachers did not give clear instructions and were not seen while giving equal chances to all students. This practice contradicts the idea raised by Brown [13] that teachers should have equal participation and motivate their learners while presenting different activities. Therefore, the ultimate findings of the present study correspond with the results of Abdisa [10], but they are indifferent from the results of Brown [13] in that the teachers help learners with various activities.

In general, the data showed that teachers hardly encourage their students while presenting speaking activities. Thus, the present results of the study show more coherence with those of the study conducted by Abdisa [10]. Therefore, teachers have a significant role in creating a conducive environment for their learners by using suitable strategies in their classrooms. Furthermore, scholars such as Littlewood [23] disclosed the roles a language teacher needs to play in communicative classrooms, such as needing analysts, counselors, providing different activities, managers, making clear instructions, and resource being a knowledge provider, which offers the necessary help when the learners are missing and they deserve assistance. As the reviewed literature shows, the roles of teachers and students are different. However, according to the findings of this study, teachers' lack of identifying their own and their students' roles affected the implementation of speaking activities.

The second research question was aimed at finding out the activities teachers use during the implementation of speaking activities. The data gathered from students' questionnaires, teachers' interviews, and classroom observations were consistent. The results indicated that teachers were not seen while using different activities in the classroom.

Furthermore, from the students' questionnaire, the respondents reported that they were not given chances due to the fact that teachers usually insisted on reading model dialogues for students. The data from the teachers' interviews confirmed that they did activities related to grammar most frequently.

Therefore, as recommended by Shrouf [19], using different modern activities to teach speaking skills, the teachers mainly used the traditional approach (teacher-based activities) for most of the observation sessions. The activities used by EFL teachers were questions and answers, explanations, and dialogues or drills. Hence, the four teachers were not using effective activities, which are suitable for the implementation of speaking activities. The results of the study showed that the teachers' use of speaking activities is inconsistent with that of research [19]. Teachers were not seen using active learner-learner joint discussions (group discussions), oral reports, role play and dramatization, interviews, information gap filling, brainstorming and simulation, picture describing, retelling stories, and language games. This result also has a similar relationship to the study conducted by Gudu [7]. He found that there was a variation in the use of classroom activities. For example, discussion was the most used classroom activity, while oral drill was the least used during classroom discussions. Teachers did not integrate various classroom activities into one lesson, thus indicating that teachers mostly dominate their learners while presenting speaking activities. Therefore, the results demonstrated in the findings of this study are more and less consistent with the study conducted by Gudu [7].

The third research question was aimed at knowing the manner in which EFL teachers present speaking activities in the EFL class. On this, the literature indicated that using different modern activities to teach speaking skills in a suitable way helps learners to have a clear understanding of the subject they are learning. The data from students' questionnaire and classroom observations identified that the manner in which EFL teachers present speaking activities was not in an enjoyable manner. Teachers did not present different speaking activities in their classrooms. The speaking activities that were presented by the teachers did not motivate the students to speak freely, and the speaking activities that were presented by the teachers did not incorporate the students' participation. Therefore, the current results of the study show more consistency with those of the study conducted by Abdisa [10].

The fourth research question was aimed at finding the challenges EFL teachers face during the implementation of speaking activities at the intended school. The teachers' interview indicated that teachers were not comfortable during the implementation. Because their students are worried about the language they speak, they lack the habit of communicating in front of their classmates, there is a 
shortage of time, most students read the model dialogue rather than practice it, and most students are not interested in using the target language, most teachers prefer to teach grammar rather than present speaking activities.

However, the finding of this study revealed inconsistency when teachers violated what Hedge [32] pointed out as follows: teachers should facilitate the practice of student activities to bring about effective products.... Teachers should guide a student in the performance of a task with the goal of achieving competence closer to expert performance in the way that athletic and dance and singing coaches work with their students. The authors continue to explain that "Teachers should be inspired to move beyond covering the curriculum" (P. 93). Additionally, these challenges should be reduced as asserted by Nunan [15] that "Any individual may be influenced by a variety of motivations which will affect such things as anxiety, attitude, or willingness to try new learning strategies."

Regarding the classroom observations, the findings of this study showed that most teachers were not seen while giving sufficient time for the speaking section. Even though a few teachers give sufficient time, they are not seen while encouraging students who mostly use their mother tongue. In this regard, Hedge [32] argued that student activities can provide an uneven chance for students to communicate in the target language where there is no patterned interaction.

Therefore, the results concerning the challenges that teachers encounter while presenting speaking activities indicate that teachers are still reluctant to reduce the challenges of the implementation of speaking activities and emphasize the traditional way of implementing speaking activities.

In a nutshell, the discussions focused on teachers' implementation of speaking activities, the activities teachers use in implementing speaking activities, the manner in which teachers present speaking activities, and the challenges teachers face during the implementation of speaking activities. The results clearly tried to address the basic research objectives. However, the study did not incorporate other stakeholders, such as school principals, policy makers in education, and other concerned bodies. This could have been taken as a limitation of this study. The study implicates further studies that are worth mentioning in the areas of policy education, revision of the textbook, and action study on improving teachers' implementation and learners' practice of speaking activities in the English textbook.

\section{Conclusions}

The main objective of this study was to examine EFL teachers' practice and implementation of speaking activities in the Ethiopian grade 10 English language textbook. The data were collected through a questionnaire, classroom observations, and interviews. The results confirmed that the implementation of different speaking activities in an EFL classroom is to create a conducive environment for the teaching and learning process. To do so, a great effort is expected from the teacher. However, the data showed that the teachers were not playing active roles in implementing the speaking activities that are designed in the student textbook. They did not present the speaking activities as they are given in the student textbook. It means that they present the speaking activities in a limited way. No maximum amount of implementation of speaking activities was observed by the teachers. They mainly present the grammar part in EFL classes. The data revealed that they rather focused on presenting grammar and questions and answers. Generally, teachers lack giving clear instructions, lack encouraging students, have a shortage of time, and do not help with unclear ideas. The results do not go in line with what Nunan [15] stated: teachers should determine what their students think and feel about what they want to learn. This reveals that most EFL teachers at the target school ignored implementing the speaking activities and focused on presenting grammar lessons. This might result from a lack of teachers' confidence, lack of topical knowledge, and giving less attention to classroom interaction.

Even though the activities were preferable for classroom interactions, most teachers did not implement the activities properly. For instance, after giving some issues for discussion, most teachers did not offer students an oral presentation. They make students read a model dialogue rather than practice in front of their classmates. On the contrary, the activities that were presented by the teachers were not varied. Generally, teachers know how far the activities are interactive, but they assume that it is a tireless and timeconsuming activity. This reveals that teachers did not adapt to implementing the communicative speaking activities. Rather, they relied on the traditional, which is a teachercentered way of presenting lessons.

English teachers are required to identify the challenges they face while implementing speaking activities. However, the study shows that there were major problems that teachers did not take into consideration. For instance, the shortage of time allowed for the implementation of the activities, teachers mostly using their mother tongue in the classroom, teachers' lack of motivation, poor classroom management of the teachers, and being unable to encourage and give equal chance to students.

Even though language teachers are expected to present the speaking activities by using different activities, the data indicated that the participating teachers were using similar activities, which was the teachers' dominating method. The activities mostly used were discussion, questions and answers, and explanation. In relation to this, most teachers were interested in presenting grammar in EFL classes by ignoring the speaking activities. For instance, four teachers were not seen while implementing brainstorming, information gap, story completion, and language game activities. Generally, the four teachers hardly used the activities that are advisable to implement the speaking activities. This indicates that teachers mostly dominate classroom interactions by using few activities in implementing the speaking activities. However, as indicated in the review of the related literature, this discrepancy might result from a lack of teachers' training, less exposure to the target language, and less attention given to the implementation of the speaking activities. 


\section{Data Availability}

The data that support the findings of this study are available from the corresponding author upon reasonable request.

\section{Conflicts of Interest}

The authors declare that there are no conflicts of interest.

\section{Acknowledgments}

The researchers would like to acknowledge all the English language teachers and students of Gimbo High School for their cooperation and willingness to provide the necessary data for the success of this research.

\section{References}

[1] H. G. Widdowson, Teaching Language as Communication, Oxford University Press, Oxford, UK, 1978.

[2] P. Ur, A Course in Language Teaching. Practice and Theory, Cambridge University Press, Cambridge, UK, 2004.

[3] A. Amanuel, "A study on the problems that affect students' english speaking skill: homecho secondary school in focus, SNNPR," Unpublished MA Thesis, Addis Ababa University, Addis Ababa, Ethiopia, 2015.

[4] J. C. Richards, Methodology in Language Teaching. An Anthology of Current Practice, Cambridge University Press, Cambridge, UK, 2002.

[5] Minstry of Education, Listening and Speaking: Secondary Teachers' Booklet. Module 2\&3. Printed by EMPDE, Minstry of Education, Delhi, India, 2005.

[6] O. Tamiru, Students' and teachers' use of English as the medium of instruction in NEKEMTE TOWN grade 9 history and geography classes: oral interaction in focus, Unpublished Ph.D. Dissertation, Addis Ababa University, Addis Ababa, Ethiopia, 2013.

[7] B. O. Gudu, "Teaching speaking skills in english language using classroomactivities in secondary school level in eldoret municipality," Journal of Education and Practice, vol. 6, no. 35, pp. 55-63, 2015.

[8] X. Hu and X. Huang, Teachers' and Students' Perceptions of Classroom Activities Commonly used in English Speaking Classes, Canadian Center of Science and Education, Toronto, Canada, 2015.

[9] A. B. Abu-Ghararah, "Problems with speaking activities in the Saudi EFL classroom,” AWEJ, vol. 5, pp. 276-287, 2014.

[10] G. Abdisa, "The practice of teaching speaking skills," Unpublished MA Thesis, Addis Ababa University, Addis Ababa, Ethiopia, 2011.

[11] T. Sisay, "Assessing the challenges of teaching speaking skill in a large classroom in ethiopian context," Unpublished MA Thesis, Haramaya University, 2013.

[12] D. Nunan, Practical English Language Teaching, McGrawHill, Boston, MA, USA, 2003.

[13] H. D. Brown, Teaching by Principles: An Interactive Approach to Language Pedagogy, Longman, New York, NY, USA, 2nd edition, 2001.

[14] T. S. Rodgers and J. C. Richards, Approaches and Methods in Language Teaching, Cambridge University Press, Cambridge, UK, 1986.

[15] D. Nunan, Designing Tasks for the Communicative Classroom, Cambridg University Press, New York, NY, USA, 1989.
[16] S. Thornbury, How to Teach Speaking, Pearson Educational Limited, London, UK, 2005.

[17] P. Ur, Discussions that Work, Cambridge University Press, Cambridge, UK, 2005.

[18] W. Littlewood, "Communicative and task-based language teaching in East Asian classrooms," Language Teaching, vol. 40, no. 3, pp. 243-249, 2007.

[19] D. Shrouf, Teaching and Improving Speaking Skill, Philadelphia University, Amman, Jordan, 2012.

[20] M. Parrott, Tasks for Language Teachers, Cambridge University Press, Cambridge, UK, 1993.

[21] J. Harmer, The Practice of English Language Teaching, Longman, New York, NY, USA, 1991.

[22] B. Bryson, Mother Tongue, Harper Collins, New York, NY, USA, 2003.

[23] W. Littlewood, Communicative Language Teaching: An Introduction, Cambridge University Press, Cambridge, UK, 2002.

[24] J. Harmer, "The cuddle factor," Practical English Teaching, vol. 11/12, 1991.

[25] J. Gerring, Case Study Research: Principles and Practices, Cambridge University Press, Cambridge, UK, 2007.

[26] R. K. Yin, Case Study Research: Design and Methods, Sage Publications, Thousand Oaks, CA, USA, 1984.

[27] O. A. J. Lund, Research Proposal on Sampling Techniques, Danish research Copenhagen, Denmark, 2010.

[28] L. W. Neuman, Basics of Social Research: Qualitative and Quantitative Approach, Pearson Education Inc, Boston, MA, USA, 2007.

[29] L. Cohen, L. Manion, and K. Morrison, Research Methods in Education, Routledge Falmer, London, UK, 5th edition, 2000.

[30] K. Yeabsira, "Problems affecting the implementation of cooperative learning," MA Thesis, Addis Ababa University, Addis Ababa, Ethiopia, 2015.

[31] J. W. Keefe and J. M. Jenkins, Instruction and the Learning Environment, Eye on Education Inc., New York, NY, USA, 1997.

[32] T. Hedge, Teaching and Learning in the Language Classroom, OUP, Oxford, UK, 2000. 